\title{
Büyükkumla Barajı'nda Bulamaç Hendeği Yöntemi ile Geçirimsizlik Perdesi Uygulaması ve Sizma Analizi
}

\author{
Eda Nur ÇAKIR*1 ${ }^{*}$, Yeşim Sema ÜNSEVER² \\ 1,2Bursa Uludağ Üniversitesi, Mühendislik Fakültesi, İnşaat Mühendisliği Bölümü, 16059, Bursa, Türkiye
}

(Alınış / Received: 28.05.2019, Kabul / Accepted: 25.10.2019, Online Yayınlanma / Published Online: 30.12.2019)

\author{
Anahtar Kelimeler \\ Ön yüzü beton kaplı kaya dolgu \\ barajlar, \\ Büyükkumla barajı, \\ Geçirimsizlik perdesi, \\ Bulamaç hendeği, \\ Sizma analizi, \\ Seep/w
}

Özet: Ön yüzü beton kaplı kaya dolgu olan Büyükkumla Barajı, Bursa'nın Gemlik ilçesinin 10,00 km kuzeybatısında, Büyükkumla deresi üzerinde yer almaktadır. Gemlik İlçe Merkezi, Küçükkumla, Büyükkumla, Narll, Gençali, Kurşunlu ve Umurbey yerleşim yerlerine yılda 19 milyon $\mathrm{m}^{3}$ içme, kullanma ve endüstri suyu sağlanması amaçlanmaktadır. Temel kotu $-10,00$ m olan barajın kret kotu 68,00 $\mathrm{m}$, parapet kotu 70,00 m, kret genişliği 10,00 m' dir. Büyükkumla barajının kret uzunluğu ise $385,00 \mathrm{~m}$ ' dir. Derivasyon 3,00 m çapında tünel ile sağlanmaktadır. Dolusavak tasarımı eşik genişliği $25,00 \mathrm{~m}$, yandan alışlı ve kontrolsüz olarak yapılmıştır. Baraj temeli için kazı çalışmaları deniz seviyesi altında gerçekleşmiştir. Baraj gövde kazılarının kuru bir ortamda yapılabilmesi için deniz suyu ve yer altı suyu etkilerinin uzaklaştırılması zorunlu hale gelmiştir. Bu sebeple geçirimsizlik perdesi uygulanarak deniz suyu etkisi baraj rezervuarından uzaklaştırılmış, baraj gövdesi altındaki sızıntılar kontrol altına alınmıștır. Bu metot, Türkiye'de ilk kez yer altı suyu etkisinden uzaklaşmak amacı ile Aslantaş Barajı'nda uygulanmış ve başarılı olunmuştur. Geçirimsizlik perdesi yönteminde amaç sızmayı engellemek veya sızma boyunu uzatmaktır. Büyükkumla Barajında memba ve mansap batardoları altında, batardo eksenleri boyunca geçirimsizlik perdesi uygulanmıştır. Bu makalede, Seep/w programı kullanılarak geçirimsizlik perdelerinin modellemesi yapılmış ve analiz sonuçları araziden alınan ölçümlerle karşılaştırılmıştır.

\section{Application and Seepage Analysis of Cutoff Wall with Slurry Trench Method in Buyukkumla Dam}

\section{Keywords}

Concrete faced rockfill dams, Buyukkumla dam,

Cutoff wall,

Slurry trench,

Seepage analysis,

Seep/w

\begin{abstract}
Buyukkumla Dam, which is a concrete faced rockfill dam is located on Buyukkumla stream, 10,00 km northwest of Gemlik district of Bursa. It is intended to provide drinking and industrial water of 19 million $\mathrm{m}^{3}$ per year to Gemlik, Kucukkumla, Buyukkumla, Narli, Gencali, Kursunlu and Umurbey region. The dam has $-10,00 \mathrm{~m}$ foundation level and $68,00 \mathrm{~m}$ crest level, where the parapet elevation is $70,00 \mathrm{~m}$. The crest width and length of Buyukkumla Dam are $10,00 \mathrm{~m}$ and $385,00 \mathrm{~m}$, respectively. The diversion is provided by a tunnel with a diameter of $3,00 \mathrm{~m}$. Spillway is designed with a threshold width of $25,00 \mathrm{~m}$, hand-held and uncontrolled. The excavation of the foundation of the dam was carried out below sea level. In order to make the dam body excavations in a dry environment, it was mandatory to eliminate seawater and groundwater effects. Therefore, by applying slurry trench, seawater effect was removed from the dam reservoir and the leaks under the dam were taken under control. This method was applied first time at the Aslantas Dam in Turkey and became successful to eliminate the effect of ground water level. In the slurry trench method, the purpose is to prevent leakage or to prolong the infiltration. In Buyukkumla Dam, slurry trench along the axillary axes was applied under upstream and downstream cofferdams. In this article, cutoff walls were modeled by using Seep/w program and the results of the field measurements were compared with the analysis results.
\end{abstract}




\section{Giriş}

Bulamaç hendeği yöntemi ile yapılan geçirimsizlik perdesi, baraj ve diğer yapıların inşası sırasında su sızıntılarını önlemek ve kazıların kuruda yapılmasını sağlamak amacı ile inşa edilir. Bu yapı, temeli derin olan alüvyon dolgu barajların güvenliğinde önemli rol oynamaktadır. Ayrıca barajın altındaki sızıntının kontrolü ile direk bağıntılıdır.

Derinlik arttıkça duvar elemanlarında kayma ve bozulma meydana gelebilmektedir. Ayrica hepsi tek bir amaca yönelik kullanıldığı için ekonomik olmayabilmektedir. Mevcut özellikleri göz önüne alındığında; istenilen derinlikte inşa edilmesi, ekonomik olması, geçirimsiz olması ve kolay inşa edilebilir olması sebebi ile bulamaç hendeği yöntemi sıklıkla tercih edilmektedir [1].

Geçirimsilik perdeleri yer altı suyunu kesmek veya kontrol etmek amacl ile tasarlanmaktadır [2]. Alüvyon tabakasının kaldırılmasının mümkün olmadığı durumlarda; derin kazıların yapılacağı temellerde en etkili yöntem, bulamaç hendeği yöntemiyle geçirimsizlik perdesinin oluşturulmasıdır. Bulamaç hendeği yönteminde hendek stabilitesini sağlamak amacıyla vizkositesi yüksek akışkanlar doldurularak kazılar desteklenir, olușturulan bu geçirimsizlik duvarlarının taşıyıcılı̆̆ı yoktur. Geçirimsizlik perdesi, sızma boyunu uzatmak veya sızmayı engellemek için kullanılabilir. Kazı derinlikleri kullanılan makine cinsine göre değişmektedir. Uluslararası Büyük Barajlar Komitesi, farklı ekipmanlar için uygulanabilir en büyük kazı derinliklerini önermiştir [3].

Bulamaç hendeği denemeleri Veder tarafından 1948 yılında başlamıştır. Ancak ilk kez 1950 yılında İtalya'daki Fedala Barajında ve Venafro' daki Volturna Nehri üzerindeki hidrolik çalışmalarda uygulanmıştır [4]. Ülkemizde de çeşitli uygulamaları mevcuttur. Bunlardan birincisi, Aslantaş Barajı' dır. Bulamaç hendeği baraj temeli içerisinde uygulanmıştır [5]. İkinci uygulama, Tahtalı Barajı' nda baraj altı geçirimsizlik perdesi şeklinde olmuştur. Üçüncü uygulama ise Dalaman-Akköprü Barajı memba ve mansap batardolarında yapılmıștır [6].

Geoteknik mühendisliğinde barajlarla birlikte inşa edilen geçirimsizlik perdelerinin sızma davranışını tahmin etmek önemlidir. Bu sebeple birçok çalışmada sızma modeli ve analizleri yapılmıștır.

Rulon (1985) şev içerisine gömülü filtre tabakası bulunan ölçekli şev modeli inşa edip, şev tepesinden suyu damlalar halinde dökmüş̧ür. Oluşturduğu modelde, çeşitli noktalarda boşluk suyu basıncını ölçmek için zemin yüzeyi boyunca ölçüm aletleri yerleştirmiştir. Sonuçlar neredeyse orijinal laboratuvar ölçümleri ile özdeştir. Eş potansiyel çizgilerin konumu biraz farklı fakat su düzeyleri aynıdır. İki durumda da sızma alanı şev dışındadır [7].

Homojen toprak dolgu bir baraj olan Mardi Barajı Avusturya Wyong' dadır. Baraj gövdesindeki sızmalar ölçülmüsş, üzerinde çalışılmış ve sayısal veriler hesaplanarak mevcut verilerle karşılaştırılmıştır. Akım ağlarını belirlemek için sonlu elemanlar metodu kullanılmıştır. Yatay ve düşey iletkenlik katsayı oranlarının sadece debiyi etkilediği, piyozometrik yükseklikleri değiştirmediği görülmüştür. Sonuç olarak ise piyozometre ölçümlerinden alınan sonuçlar ile hesaplamaların uyumlu olduğu görülmüştür [8].

1995 yılında inşa edilen Sazlıdere Barajı gövdesi inşaatı aşamasında, zemindeki alüvyon tabaka kaldırılmış ve gövde kireç taşı tabakası üzerine oturtulmuştur. Sazlıdere Barajı gövde altı sızmaları için matematiksel model olan sonlu farklar metodu kullanılmış, akım fonksiyonları elde edilerek sızma debileri hesap edilmiştir. Metodun uygulanması sonucu baraj gövdesinin altında sızdırmazlığın sağlanabilmesi için 55,00 m' lik enjeksiyon perdesinin yeterli olacağı görülmüştür [9].

İzmir ilinde bulunan Şerefhisar Barajı akarsu yatağından $57,50 \mathrm{~m}$ yükseklikte bulunmaktadır. Farklı permeabilite katsayıları için toplam su yükleri gövde boyunca belirlenmiş ancak Seferihisar Barajı' nda gerçek sızma değerleri ölçülmediği için sızma miktarları karşılaştırılamamıştır [10].

Türkiye' nin ilk ön yüzü asfalt kaplı kaya dolgu barajı olan Muratlı Barajı' nın inşa aşamasında ve rezervuar dolumu sirasinda temeldeki sızma durumu incelenmiştir. Kil çekirdek hendeğinin (geçirimsizlik duvarı) ön tarafinda yer alan piezometreler rezervuar seviyesine göre değişiklik gösterirken, alt kısımdaki piezometrelerin rezervuar dolumundan fazla etkilenmediği görülmüştür. Eldeki verilerin, yapılan analizlerle kıyaslandığında uyumlu olduğu görülmüştür [11].

Toprak dolgu bir baraj olan İlam Barajı üzerinde Seep/w programı kullanılarak sızma analizleri yapılmıștır. Baraj kesiti boyunca toplam akış hızı ve ağ boyutunun değerlendirilmesi için, kaba, orta, ince ve yapılandırılmamış dört ağ boyutu göz önünde bulundurulmuş ve sonuç olarak, İlam Barajı için farklı ağ boyutu altındaki ortalama kaçak akış hızının, baraj kesiti boyunca saniyede 0,836 litreye eşit olduğu görülmüştür [12].

İçme suyu amaçlı yapılan ve Aydın ilinde bulunan İkizdere Barajı temelden 108,00 $\mathrm{m}$ yükseklikte bulunmaktadır. Düzlemsel akım prensibi ile analizler yapılmıștır. Barajın çeşitli gövde kesitleri ve tabanı iki boyutlu olarak incelenmiștir. Yapılan analizlerin amacl, inşaat sonu baraj gövdesinde oluşan sızma değerleri ile teoride olması öngörülen sızma değerlerini karşılaştırmaktır. Analiz sonucunda ise 
piezometre cihazlarından elde edilen okumaların analizlerde gözlenen sızma değerlerine göre daha az olduğu tespit edilmiştir. Kısaca İkizdere Barajı gövdesinde oluşan sızma değerleri eldeki verilerle yapılan hesaplarla kiyaslanınca güvenli tarafta kalındığı gözlemlenmiştir [13].

Kula (2016) çalışmasında Acrylamide-grouted kum kolonları kullanarak dolgu barajlarda sızmayı ve ani su düşüşü sırasında memba şev stabilitesini kontrol etmiștir. Modelleme Seep/w programı ile yapılmıștır. $\mathrm{Bu}$ çalıșmada permeabilite katsayısının dane boyutu ve dağılımından etkilenmediği belirlenmiștir [14].

Büyükkumla Barajının en önemli özelliği baraj temel kotlarının deniz seviyesinin altında olmasıdır. Kazı sırasında baraj denize yakın olduğu için deniz suyu ve yer altı suyu etkisinden dolayı kazı alanı su ile dolmuştur. Alüvyon tabakasının tamamen kaldırılması mümkün olmadığı için sızıntıları kontrol altına almak ve gövde temel kazısına gelecek su miktarını azaltmak amacıyla yeterli geçirimsizliği sağlamak için geçirimsizlik perdesi yapma zorunluluğu doğmuştur. $\mathrm{Bu}$ çalışmada da geçirimsizlik perdesi uygulamasına ait sızma analizleri yapılarak sonuçlar; araziden alınan ölçümlerle ile karşılaştırılmıştır.

\section{Büyükkumla Barajı' nda Bulamaç Hendeği Yöntemi ile Geçirimsizlik Perdesi Uygulaması}

Geçirimsizlik perdesi uygulaması, kılavuz duvarların inşasından sonra hendeklerin kazılması ile başlar. Kazıdan hemen sonra hendek; bentonit, su ve bazen polimer katkı karışımı olan bir destekleme malzemesiyle doldurulur. $\mathrm{Bu}$ malzeme kazının desteklenmesi için kullanılır. Destekleme işleminden sonra, hendek bentonit, su ve çimentonun uygun bir karışımını içeren plastik beton ile doldurulur. $\mathrm{Bu}$ sırada bentonit kazıyı terk eder ve aynı anda plastik beton ile yer değiştirir. $\mathrm{Bu}$ işlem hendek ekseni boyunca şaşırtmalı olarak yapılır [15].

Büyükkumla Barajında çalıșmalara ilk olarak memba ve mansap batardoları temelinde jeolojik kesitler çıkarılarak başlanmıştır. Jeolojik kesitler Şekil 3'te gösterilmiştir. Daha sonra ise jeolojik yapıya uygun geçirimsizlik perdesi projelendirilmesi yapılmıştır. Projelendirmeler, memba ve mansap batardoları altında, batardo eksenleri boyunca ve alüvyon zeminden ana kayaya 2,00 m soketleme olacak şekilde hazırlanmıștır.

Kazılara başlamadan önce hendeklerin tek bir doğrultu üzerinde olması için çalışma alanı olan kılavuz duvarlar inşa edilmiştir. Bu şekilde kontrollü bir hizalama ve çalışma alanı sağlanmıştır. Öncelikle birincil ano olarak tanımlanan ana (P) panellerin kazısına başlanılır. Ana panel geri dolgu işlemleri bittikten sonra ise ikincil ano olan kesme (S) panelleri kazılır. İkincil panele başlamadan önce her iki yanındaki birincil panel tamamlanmış ve mukavemet kazanmış olmalıdır. Ano dökümleri Şekil 1' de gösterilmiştir. Genellikle birincil ve ikincil panel arasındaki döküm 48 saat dikkate alınarak yapılmaktadır [16]. Bu sayede zemin göçmelerini en aza indirerek panellerin tek doğrultu üzerinde olması sağlanır.

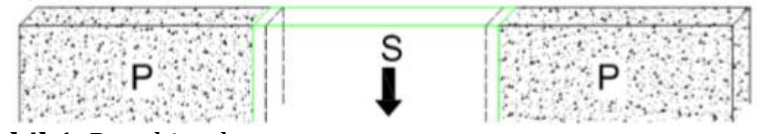

Şekil 1. Panel imalatı

Memba batardosu geçirimsizlik perdesi hattı uzunluğu 211,94 $\mathrm{m}$ olup 39 adet 3,13 metre uzunluğunda Birincil (P) anolar ve 38 adet 3,13 m uzunluğunda İkincil (S) anolar olmak üzere toplamda 77 ano bulunmaktadır. Birincil anolara ana paneller (anolar) ikincil anolara ise kesme panelleri de (anoları) denir.

Mansap batardosu geçirimsizlik perdesi hattı uzunluğu ise $270,65 \mathrm{~m}^{\prime}$ dir. 0+000 - 0+104,65 metreler arası 3,13 m uzunluğunda 19 adet (P) anoları ve bu (P) anolarını kesen 19 adet 3,13 m uzunluğunda (S) anoları mevcuttur. 0+104,65 $0+269,92$ metreleri arasında ise 2,80 m uzunluğunda 35 adet $\mathrm{P}$ anoları ve bu anoları kesen 34 adet $\mathrm{S}$ anoları olmak üzere toplamda 107 ano bulunmaktadır. Mansap batardosu geçirimsizlik perdesi uygulaması deniz etkisini azaltmak için memba batardosundaki uygulamadan büyük yapılmıştır.

Büyükkumla Barajı memba batardosu ve mansap batardosu üzerindeki geçirimsizlik perdesi imalatlarına 15.04.2015 tarihinde başlanılmış olup 28.08.2015 tarihinde tamamlanmıştır. Büyükkumla Barajı' nda geçirimsizlik perdesi imalatında; 1 adet Hidrolik Kelly Grab, 2 adet vinç, 2 adet bentonit çamuru üretim santrali, 4 adet bentonit çamuru dinlendirme havuzu ve 2 adet kum eleme ünitesi kullanılmıştır. Bentonit havuzunda sürekli hava sirkülasyonu ile bentonit karışımının çökmesi engellenir. Bentonit havuzuna ait fotoğraf Şekil 2' de gösterilmiştir.

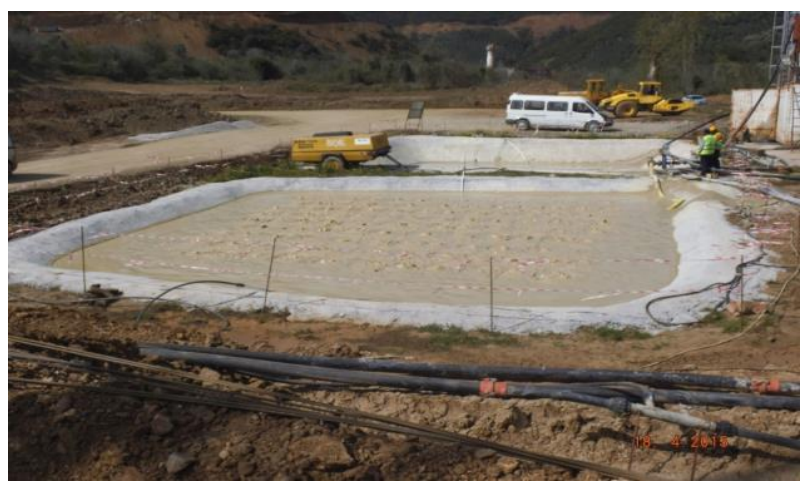

Şekil 2. Bentonit dinlendirme havuzu 

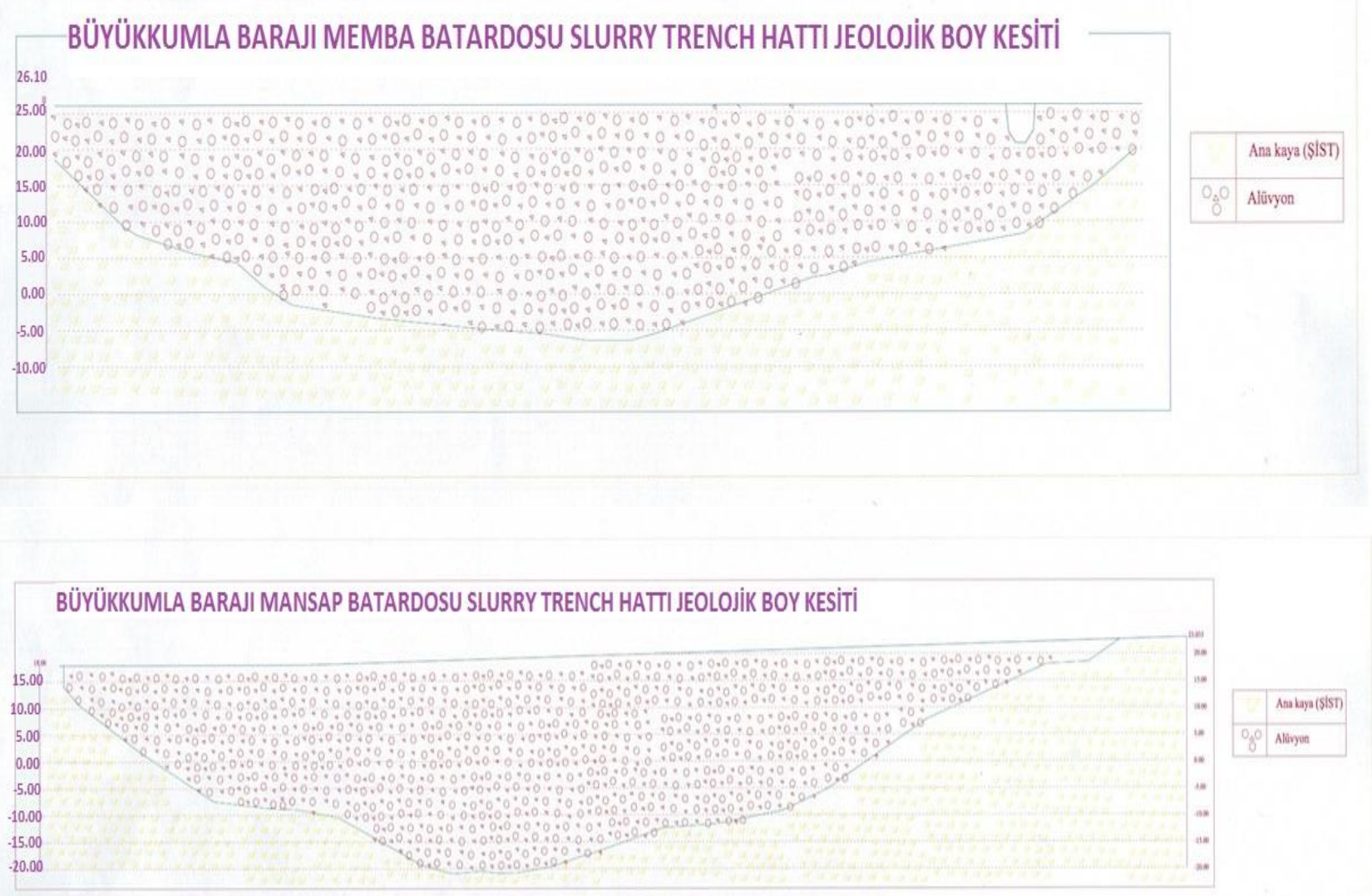

Şekil 3. Memba ve mansap batardosuna ait jeolojik kesit

\section{Büyükkumla Barajı' nda Geçirimsizlik Perdesi Sizma Analizi}

Temelden ve baraj gövdesinden meydana gelebilecek sızıntı miktarının hesaplanması, sızma problemlerini kontrol altına almak veya sızmayı azaltmak için gereklidir [17]. Geoteknik mühendisliğinde sızma davranışını tahmin etmek birçok değişken nedeni ile zordur. Sızma sorunlarının değerlendirilebilmesi için kapsamlı bir araştırma yapılmalıdır.

Hidrodinamik kurallara göre su kendisine sürtünmesiz ve en rahat yolu seçerek gövde içerisinde borulanmalara sebep olabilir. Dolgu barajlarda bu kaçınılmazdır [18].

Permeabilite, sızma davranıșında en önemli faktör olup ölçülmesi zor bir parametredir. Yüzeylerde gözlemlenen sızmalar, iç kısımlardaki borulanmalar ve tehlikeli sızıntılar hakkında bilgi verebilir. Sızmanın zamana bağlı artıp azalması, borulanmaların kendi kendine tıkanması veya büyümesi sürecini gösterebilir [19].

Sızma analizi Darcy (1956) Yasası ile mümkün olmuştur. Darcy yasası;

$$
Q=k * i * A
$$

formülü ile gösterilir. Formülde,
Q: Debi

$k$ : Hidrolik iletkenlik katsayısı

$i$ : Hidrolik eğim

$A$ : Kesit alanı ifade etmektedir.

İki boyutlu sızma için;

$$
\frac{\partial}{\partial x}\left(k x \frac{\partial H}{\partial x}\right)+\frac{\partial}{\partial y}\left(k y \frac{\partial H}{\partial y}\right)+Q=\frac{\partial \Phi}{\partial t}
$$

formülü kullanılır. Formülde,

$H$ : Toplam hidrolik yük

$k_{\mathrm{x}}$ ve $k_{\mathrm{y}}$ : sırasıyla $\mathrm{x}$ ve $\mathrm{y}$ yönlerinde ki hidrolik iletkenlik katsayısı

Q: Su miktarı

$t$ : Zaman

$\Phi$ : Hacimsel su içeriği' ni vermektedir.

$\mathrm{Bu}$ denklem, $\mathrm{x}$ ve $\mathrm{y}$ yönünde uygulanan akımın zamana bağlı olarak hacimsel su içeriğine eșit olduğunu belirtir. Kararlı durum koşullarında, sisteme giren ve çıkan akış her zaman eşittir [20].

Sızmaya ilişkin geçerli diferansiyel denklemleri çözmek için sonlu elemanlar yaklaşımını yapabildiğimiz Seep/w yazılımı kullanılabilir. Seep/w, gözenekli zeminlerde sızma problemlerini tespit etmek için kullanılan Geo-Slope yazılımının bir alt programidır [21]. 
Geçirimsizlik perdesinin yeterliliğini ölçebilmek ve imalat sonrasında oluşabilecek sızma miktarını tespit etmek amaciyla sonlu elemanlar yöntemini kullanan Seep/w gerçek süreçlerin simülasyonudur.

Sayısal modellemenin fiziksel modellemeye göre daha hızlı yapılabilmesi, herhangi bir araç gerektirmemesi, farklı senaryoların incelenebilmesi ve ekipman gerektirmemesi gibi birçok avantajı vardir [20].

Sızma analizinde iki durum vardır. Bunlardan birisi suyun akış hızının ve su basınçlarının değişmediği kararlı durum analizidir. $\mathrm{Bu}$ analiz zamanı görmezden gelir ve denklemleri basit hale getirir. Diğeri ise zaman içerisinde basınç değişimini göz önünde bulundurur. Zemin koşullarına göre daha doğru sonuçlar verir ancak kararlı durum analizlerine göre daha karmaşıtır [14]. Yapılan çalışmada kararlı durum analizleri kullanılmıştır.

Memba ve mansap batardoları gerçek inşaat koşullarına göre modellenmiştir. Memba ve mansap şev eğimleri 1/1 olacak şekilde tasarlanmıştır. Memba batardosunun kret kotu 26,00 m, mansap batardosunun ise $18,00 \mathrm{~m}^{\prime}$ dir. Şekil 4'te memba batardosuna ait modelleme gösterilmiştir.

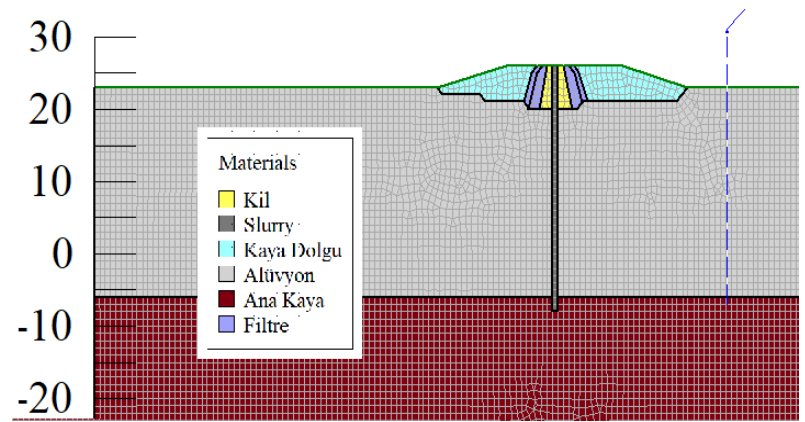

Şekil 4. Memba batardosu, geçirimsizlik perdesi en kesiti ve sonlu elemanlar ağı $(1 \mathrm{mx} 1 \mathrm{~m})$

Modellemede kullanılan malzemelerin hidrolik iletkenlik katsayısı değerleri Tablo 1' de verilmiștir. Bu değerler, Büyükkumla Barajı' na ait Doğal Yapı Gereçleri Raporu' ndan elde edilmiştir.

Tablo 1. Modelde yer alan tabakaların hidrolik iletkenlik katsayısı değerleri

\begin{tabular}{cc}
\hline Malzeme & k (m/sn) \\
\hline Kaya Dolgu & $1 \times 10^{-4}$ \\
Filtre Malzemesi & $1 \times 10^{-3}$ \\
Kil & $6 \times 10^{-8}$ \\
Alüvyon & $1 \times 10^{-3}$ \\
Ana Kaya & $1 \times 10^{-6}$ \\
Geçirimsizlik Perdesi & $1 \times 10^{-9}$ \\
\hline
\end{tabular}

Memba batardosu ekseninde bulanan geçirimsizlik perdesi yer altı suyunu kontrol etmek amacı ile inşa edilmiştir. $\mathrm{Bu}$ nedenle modelde sınır koşulu olarak yer altı su seviyesi membada 23,00 m olarak programa tanımlanmıştır. Mansapta ise sınır koşulu olarak yerinde yapılan ölçümler sonucu elde edilen 8,00 m programa tanımlanmıştır.
Ağ boyutunun $5 \mathrm{mx} 5 \mathrm{~m}^{\prime}$ den $1 \mathrm{mx} 1 \mathrm{~m}$ olarak değiștirildiğinde, sızmanın azaldığı ancak serbest su akımı yüzeyinin değişmediği Kula [14]'nın çalışmasında bildirilmiştir. Bu sebeple çözüm için en uygun değerin $1 \mathrm{mx} 1 \mathrm{~m}$ olacağına karar verilmiştir. Modelleme Şekil 4'te gösterilmiştir.

Modelleme yapıldıktan sonra sızma analizi yapılarak eş potansiyel eğrileri, sızan toplam debi ve toplam yükler elde edilmiştir. Şekil 5'te görüldüğü üzere toplam yük sağ tarafta $16,00 \mathrm{~m}^{\prime}$ de kalmakta, su vektörleri geçirimsizlik perdesinden sonra azalmaktadır. Serbest su akımı yüzeyi, kil dolgu ve geçirimsizlik perdesi içerisinde azalarak ana kaya içerisinde kalmıştır. $\mathrm{Bu}$ durum geçirimsizlik perdesinin geçirimsizliğini ispat etmektedir. Geçirimsizlik perdesi uygulaması sayesinde su seviyesi düşürülmüş ve sızma kontrol altına alınmıştır.

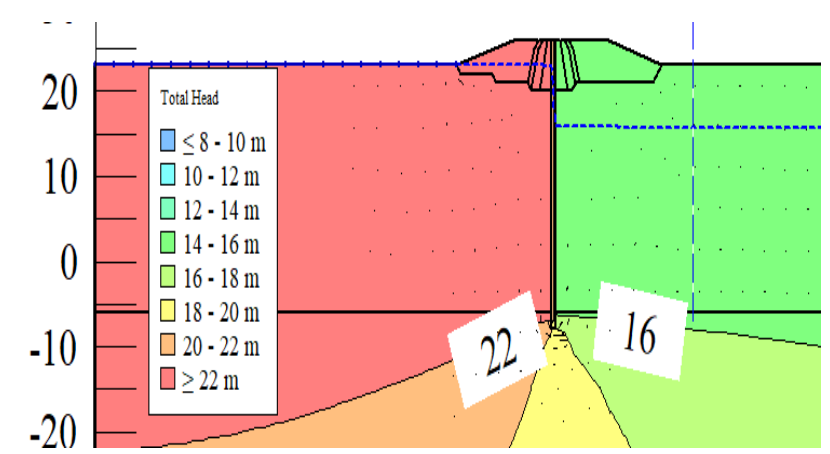

Şekil 5. Sızma analizi sonucu memba batardosunda toplam yükler ve serbest su akımı yüzeyi

Şekil 6'da mansap batardosunun sizma analizi sonuçları görülmektedir. Şekilde görüldüğü gibi geçirimsizlik perdesinin sağ tarafında toplam yük 10 m olmasına rağmen sol tarafta toplam yük 14,00 m' de kalmaktadır. Analiz sonucu elde edilen sizma debisi de aynı şekil üzerinde gösterilmiştir. Mansap batardosu için hız vektörlerinin ana kayada azaldığ ve sızma debisinin ise $3,98 \times 10^{-6} \mathrm{~m}^{3} / \mathrm{sn}$ olduğu görülmüștür.

Geçirimsizlik perdesi yapımı sonrası, arazide kontrol amaciyla memba ve mansap batardosu etrafinda kuyular açılmıştır. Memba batardosu kontrol kuyularında toplam yüklerin ortalama $13,00 \mathrm{~m}$ olduğu, mansap batardosu etrafindaki kontrol kuyularında ise 8,00 m olduğu gözlemlenmiştir.

Tablo 2' de arazide yapılan ölçümler ve Seep/w sonlu elemanlar yazılımı ile yapılan analizlerin sonuçları karşılaştırılmıştır. Tablodan görüldüğü üzere arazide alınan ölçümler ile analiz sonuçlarının her iki batardonun da memba tarafında yakın değerler verdiği görülmüştür. Batardoların mansap taraflarında ise analizden elde edilen sızma değerlerinin gerçek değerlerden yüksek çıktığı ve programların güvenli tarafta kaldığı tespit edilmiştir. Ana kayaya 2,00 m soketlenen geçirimsizlik perdesi sızmayı azaltarak suyun yükselmesini engellemiştir. 
Arazide sızmaya ait ölçüm yapılmadığı için analiz sonuçları ölçümlerle karşılaştırılamamıștır.

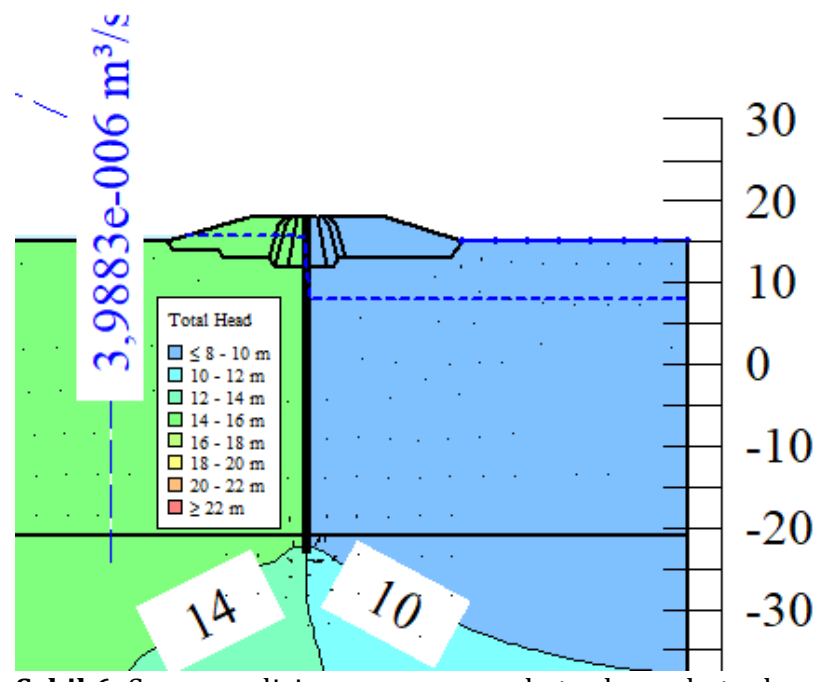

Şekil 6. Sizma analizi sonucu mansap batardosunda toplam yükler ve serbest su akımı yüzeyi

Tablo 2. Analizler ve arazi ölçümleri sonucu elde edilen toplam yükler

\begin{tabular}{ccc}
\hline & $\begin{array}{c}\text { Seep/w } \\
\text { (m) }\end{array}$ & $\begin{array}{c}\text { Arazi Ölçüm Sonuçları } \\
\text { (m) }\end{array}$ \\
\hline Memba Batardosu & 22 & 22 \\
& 16 & 13 \\
Mansap Batardosu & 10 & 10 \\
& 14 & 8 \\
\hline
\end{tabular}

\section{Tartışma ve Sonuç}

Bu çalışmada, Büyükkumla Barajı' nın gövde kazılarının kuru ortamda yapılabilmesi ve yer altı su seviyesinin kontrol altına alınması amacıyla memba batardosu altında yapılan ve barajın kullanımı sırasında yer altı su seviyesinin ve deniz suyu etkisinin kontrol altına alınması amacıyla mansap batardosu altında yapılan geçirimsizlik perdesi uygulamalarından bahsedilmiștir. Mansap batardosu altında bulunan geçirimsizlik perdesi memba tarafındakinden daha uzun inşa edilmiştir. Bunun sebebi ise deniz suyu etkisinin baraj çalışma sahasına kadar ulaşmasıdır.

Ayrıca, memba ve mansap batardosu için Seep/w sonlu elemanlar yazılımı ile modelleme ve sızma analizleri yapılmıștır. Modellemeler, gövde kazılarına bașlanılmadan önceki zemin şartları göz önünde bulundurularak hazırlanmıştır.

Modellemeler sonucu elde edilen toplam yükler arazi ölçüm değerleri ile de karşılaştırılmıştır. Karşılaştırma kapsamında arazide yapılan sondaj kuyuları ve kontrol kuyuları ölçüm sonuçları kullanılmıştır. Arazide alınan ölçümler ile analiz sonuçlarının her iki batardonun da memba tarafinda yakın değerler verdiği görülmüştür. Sonuçların, daha önce Muratlı Barajı' nın sızma analizi sonuçları gibi gerçek ölçümlerle yakın olduğu tespit edilmiştir [11].
Batardoların mansap taraflarında ise analizden elde edilen sızma değerlerinin gerçek değerlerden yüksek çıktığı ve programların güvenli tarafta kaldığı tespit edilmiştir. İkizdere Barajı nda yapılan analizlerde de sızmaların gerçek değerlerden yüksek çıktığl ve programın güvenli tarafta kaldığı gözlemlenmiștir [13].

Arazi ölçümleri ve analiz sonuçları göz önünde bulundurulduğunda memba ve mansap batardoları altında bulamaç hendeği yöntemi ile inșa edilen geçirimsizlik perdesinin sızdırmazlık yönünden başarılı olduğu görülmüştür.

Sonuç olarak sızma analizlerinde kullanılan Seep/w yazılımının sızma hesaplarında oldukça fayda sağladığı, çalışmaları hızlandırdığı ve sızma davranışını doğru bir şekilde tespit edebildiği gözlemlenmiştir.

İleriki çalışmalarda, toplam yüklerdeki değişimin etkisini gözlemek amacı ile geçici durum analizleri ve gövde dolgusu tamamlandıktan sonraki davranışı incelemek için gövde altı sızma analizleri yapılabilir.

\section{Kaynakça}

[1] Ariyama, M., Naito, T., Ohya, H., Arai, M. 1994. Trust Method-Thin Slurry Walls. ss. 199-206. Chamberlain, D. A., ed. 1994. Automation and Robotics in Construction Xi, Elsevier Publishing, UK, 730s.

[2] Püsküllüoğlu, A., Türkmen, S. 2012. Ceyhan Hidroelektrik Santrali Projesi (CevdetiyeOsmaniye) Regülatör Yapılarındaki Geçirimsizleştirme Yöntemleri. Ç. Ü. Fen ve Mühendislik Bilimleri Dergisi, 27(4), 91-100.

[3] Fenoux, G. Y. 1985. Filling Materials for Watertight Cutoff Walls. International Commission on Large Dams, Paris, 70s.

[4] Clayton, C. R. I. 1992. Retaining Structures. Thomas Telfard Publishing, London, 779s.

[5] Karaoğullarından, T., Özgüzel, N., Akçanbaş, N. 1977. Alüvyonda Bulamaç Hendeği (Geçirimsizlik perdesi) Yöntemiyle Sızdırmazlık Perdesi Yapımı. Jeoloji Mühendisliği Dergisi, (3), 28-35.

[6] Tosun, H., Ünal, S. M., Türköz, M. 2002. Dolgu Barajlarda Bulamaç Hendeği Yöntemi ile Plastik Beton Perde İnşası ve Bir Uygulama. Zemin Mekaniği ve Temel Mühendisliği 9. Ulusal Kongresi, 21-22 Ekim, Eskişehir, 48-57.

[7] Rulon, J. J., Freeze, R. A. 1985. Multiple Seepage Faces on Layered Slopes and Their Implications for Slope Stability Analiysis. Canadian Geotechnical Journal, 22(3), 347-356.

[8] Gan, J. K., Mc Donald, L. A., 1999. Mardi Dam A Case Study on Permeable Structures. 
International Symposium on Dam Foundations: Problems and Solutions, 23 September, Antalya.

[9] Eynur, Z. 2004. Baraj altındaki sızmaların analiz ve kontrolü: Sazlıdere Barajı uygulaması. İstanbul Teknik Üniversitesi, Fen Bilimleri Enstitüsü, Yüksek Lisans Tezi, 110s, İstanbul.

[10] Mesci, S. B. 2006. Dolgu baraj gövdelerindeki sızmaların ve freatik hattın incelenmesi: Seferhisar Barajı uygulaması. İstanbul Teknik Üniversitesi, Fen Bilimleri Enstitüsü, Yüksek Lisans Tezi, 103s, İstanbul.

[11] Ünsever, Y. S. 2007. An analysis of deformation behavior of Muratlı asphalt faced rockfill dam. Orta Doğu Teknik Üniversitesi, Fen Bilimleri Enstitüsü, Yüksek Lisans Tezi, 112s, Ankara.

[12] Hasani, H., Mamizadeh, J., Karimi, H. 2013. Satbility of Slope and Seepage Analysis in Earth Fill Dams Using Numerical Models (Case Study: Ilam Dam-Iran). Word Applied Sciences Journal, 21(9), 1398-1402.

[13] Çelik, B. 2014. Aydın İkizdere Barajı sonlu elemanlar yöntemi ile sızma analizi. Gazi Üniversitesi, Fen Bilimleri Enstitüsü, Yüksek Lisans Tezi, 63s, Ankara.

[14] Kula, H. I. 2016. Developing smart grauted sand columns for real time monitoring of the stability, seepage and rapid drawdown in earth dams.
University of Huston, Yüksek Lisans Tezi, 88s, Huston.

[15] Alp, Ö. K., Büyükçoban, H., Pelen, G. M., 2014. Bulamaç Hendeği Yöntemi ile Geçirimsizlik Perdesi İmalatı, Aslancık Barajı ve HES Örneği. 2. Barajlar Kongresi, 13-15 Şubat, İstanbul, 7-11.

[16] Anonim, 2014. Büyükkumla Geçirimsizlik Perdesi Yapım Raporu. Sonar Sondaj ve Jeolojik Araştırma Geoteknik Hizmetleri A.Ş., 27s., Ankara.

[17] Soleymani, S., Akhtarpur, A. 2011. Seepage Analysis for Shurijeh Reservoir Dam Using Finite Element Method. American Society of Civil Engineers Geo-Frontiers Congress, 13-16 March, Dallas-Texas, 3227-3234.

[18] Mortazavi, S. M., Soleimani, S. 2015. Leakage Analysis of Embankment Dams Using Seep/w, 3D Seep Software. Appl. Environ. Biol. Sci., 5(10), 122-128.

[19] Anonim, 2014. Seepage Manuel. US Bureau of Reclamation, 150s., US.

[20] Anonim, 2012. Stability and Seepage Modeling Users Guide. Geo-studio Geo Slope International Ltd., 199s., Canada.

[21] Arshad, I., Babar, M. M. 2014. Finite Element Analysis of Seepage through an Earthen Dam by Using Geo-Slope (SEEP/W) software. International Journal of Research, 1(8), 619-634. 